Brazilian Journal

of Chemical

ISSN 0104-6632

Printed in Brazil

Engineering

\title{
SEPARATION OF COPPER FROM A LEACHING SOLUTION OF PRINTED CIRCUIT BOARDS BY USING SOLVENT EXTRACTION WITH D2EHPA
}

\author{
Mónica Maria Jiménez Correa ${ }^{1 *}$, Flávia Paulucci Cianga Silvas ${ }^{1,2}$, Paula \\ Aliprandini ${ }^{1}$, Viviane Tavares de Moraes ${ }^{1}$, David Dreisinger ${ }^{3}$ and Denise \\ Crocce Romano Espinosa ${ }^{1}$
}

\author{
${ }^{1}$ Universidade de São Paulo, Escola Politécnica, Departament of Chemical \\ Engineering. do Lago, 250, 05424-970, PO 61548, São Paulo, Brazil. \\ ${ }^{2}$ Vale Institute of Technology-Mining, Av. Juscelino Kubitschek, 31, 35400-000, \\ Ouro Preto, Minas Gerais, Brazil. \\ ${ }^{3}$ Department of Materials Engineering, University of British Columbia, 309-6350 \\ Stores Road, Vancouver, B.C., Canada V6T 1 Z4.
}

(Submitted: March 15, 2017; Revised: June 1, 2017; Accepted: July 21, 2017)

\begin{abstract}
Global generation of waste electrical and electronic equipment (WEEE) is increasing quickly. Metals from WEEE can be recovered by using unit operations of chemical engineering. This paper describes a combined hydrometallurgical route (sulfuric oxidant leaching + solvent extraction) to recover copper from printed circuit boards (PCBs). A non-magnetic fraction from comminuted PCBs was used to perform leaching tests at $75^{\circ} \mathrm{C}$ for 6 hours in an oxidizing media (sulfuric acid + hydrogen peroxide). In order to separate zinc, aluminum, and copper from the leaching liquor, solvent extraction tests were carried out using D2EHPA. Parameters that influence the process, such as $\mathrm{pH}$, extractant concentration, and the aqueous/organic $(\mathrm{A} / \mathrm{O})$ ratio were investigated. Solvent extraction experiments were carried out in two stages: i) separation of zinc, aluminum, and residual iron, and ii) copper separation. The results showed that the leaching obtained around $60 \%$ aluminum, $94 \%$ copper, $76 \%$ zinc, $50 \%$ nickel and residual iron from the non-magnetic fraction of PCBs. With the solvent experiments, in the first stage, $100 \mathrm{wt} . \%$ zinc, iron and aluminum were extracted at $\mathrm{pH} 3.5,2: 1 \mathrm{~A} / \mathrm{O}, 10 \%(\mathrm{v} / \mathrm{v}) \mathrm{D} 2 \mathrm{EHPA}$, while, in the second stage $100 \%$ of the copper was extracted at $\mathrm{pH} 3.5,1: 1 \mathrm{~A} / \mathrm{O}, 20 \%(\mathrm{v} / \mathrm{v})$ D2EHPA.
\end{abstract}

Keywords: Waste electrical and electronic equipment (WEEE), recycling, printed circuit boards (PCBs), leaching, solvent extraction.

\section{INTRODUCTION}

Waste of electrical and electronic equipment (WEEE) is increasing quickly. In 2014 alone, the global generation of WEEE was 41.8 million tons
(5.9 kg per inhabitant), while in 2010 the electrical and electronic equipment (EEE) discarded was 33.8 million tons $(5.0 \mathrm{~kg}$ per inhabitant) (Baldé et al., 2015; Kane, 2015). 
WEEE recycling can help minimizing the environmental impacts caused by primary metal extraction (Flandinet et al., 2012; Hall and Williams, 2007). Several studies have shown that PCBs contain valuable metals, such as gold, silver, palladium, nickel and copper which can make the metals recovery economically viable (Jiménez Correa et al., 2014; Park and Fray, 2009; Yamane et al., 2011).

Processes for metal extraction from WEEE based on mechanical, physical, pyrometallurgical and hydrometallurgical techniques have been developed (Chen et al., 2015; Fogarasi et al., 2013; Hagelüken, 2006). In pyrometallurgical processing, the matrix is incinerated, while target metals are smelted. Hydrometallurgical processing already consists of leaching, separation, purification and electrorefining of the metals of interest (Cui and Zhang, 2008; Tuncuk et al., 2012). Compared with pyrometallurgical processing, hydrometallurgical methods present a relatively low capital cost, and are also more easily controlled and more predictable and the recovery of metals is large for small scale applications. Pyrometallurgical processing operates at high temperatures (usually greater than $1000^{\circ} \mathrm{C}$ ), consumes a lot of energy and produce hazardous gasses that must be treated with cleaning systems (Cui and Zhang, 2008; Rocchetti et al., 2013; Tuncuk et al., 2012).

In hydrometallurgical processing, metals from PCBs are solubilized by different methods acid leaching or bioleaching and the liquor can be purified by solvent extraction, selective precipitation and electrowinning (Ghosh et al., 2015; Tuncuk et al., 2012). Copper is the main metal present in PCBs and its leaching can be performed using sulfuric acid and hydrogen peroxide as an oxidant agent. Nickel, zinc and iron leaching can already be carried out using sulfuric acid. Several studies have evaluated the PCB leaching process and studied conditions, such as the solid-liquid ratio, acid concentration and temperature (Birloaga et al., 2013; Oh et al., 2003; Yang et al., 2011).
Yang et al. (2011) analyzed copper leaching from spent PCBs. The study reported copper extraction higher than 90 wt.\% using sulfuric acid, hydrogen peroxide and a solid: liquid ratio of $1: 10(\mathrm{~g} / \mathrm{mL})$, after $3 \mathrm{~h}$ at $23^{\circ} \mathrm{C}$. According to Birloaga et al. (2013) $90 \mathrm{wt} . \%$ of copper can be leached from PCBs after two leaching stages with sulfuric acid and hydrogen peroxide. Silvas et al. (2015) investigated copper leaching with sulfuric acid + hydrogen peroxide and 1:10 solid/liquid ratio at $75^{\circ} \mathrm{C}$ over $4 \mathrm{~h}$. After two successive leaching stages, $100 \%$ of the copper in comminuted PCBs was leached.

The separation of metals contained in a liquor from acid leaching can be achieved by a solvent extraction technique. The extractant di-2-ethylhexyl phosphoric acid (D2EHPA) belongs to the organic phosphonic acid class and its main characteristic is the formation of a hydrogen bond between extractant molecules, causing the formation of dimeric structures (Figure 1) (Pereira, 2006).

The solvent extraction process has been widely used in hydrometallurgical metal recycling from WEEE (Kumari et al., 2016). Provazi et al., 2011) studied metal separation from a leaching liquor of spent batteries using Cyanex 272 versus selective precipitation. The results showed that solvent extraction was more efficient in metal separation than selective precipitation. Meanwhile, Oishi et al., 2007) investigated the recovery and purification of copper from printed circuit boards using LIX 26. Solvent extraction tests found that it is possible to achieve a metal extraction rate of lead, manganese, aluminum, iron, zinc and copper higher than 92\% using LIX 26.

Several solvent extraction works have been developed to recover metals from WEEE (Dorella and Mansur, 2007; Kumari et al., 2016; Long Le et al., 2011; Nayl et al., 2015; Provazi et al., 2011). Table 1 shows some of the studies performed by different authors for metal recovery from WEEE using solvent extraction.

In this paper, a combined hydrometallurgical route was studied in order to recover and separate copper from discarded computer video PCBs using D2EHPA as extractant.

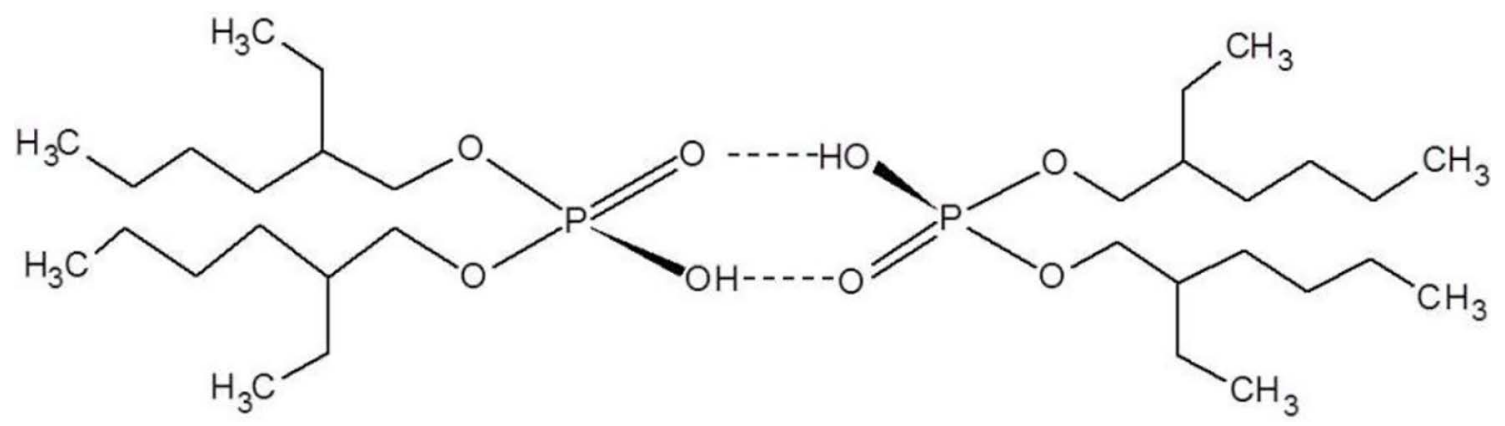

Figure 1. Dimeric structure of di-2-ethylhexyl phosphoric acid (D2EHPA) (Adapted from Pereira, 2006). 


\section{MATERIALS AND METHODS}

Printed circuit boards used in this research were collected by a waste electronics recycling center in the city of São Paulo - Brazil. Initially the manual dismantling of the printed circuit boards was performed using pliers and a screwdriver for the removal of heat sinks, screws and electrolytic capacitors. With the aid of a manual guillotine, the boards were cut into smaller pieces so that they could fit into the opening of the mill.

The comminution was made primarily by grinding the PCBs in a blade mill with a $6 \mathrm{~mm}$ grill, followed by grinding in a hammer mill with a $2 \mathrm{~mm}$ grid. According to Tuncuk et al. (2012), the full release of copper happens with a particle size smaller than $2 \mathrm{~mm}$ as, in larger particles, there can be tunneling of $\mathrm{Cu}$ on the pins of the plastic components.

The magnetic separation of the sample was performed after grinding by the hammer mill. A dry drum magnetic separator was used at the following settings: magnetic roller speed of $27 \mathrm{rpm}$; vibration percentage of the feed $25 \%$. In the present study, the material used was the non-magnetic fraction of PCBs. The sample was characterized by inductively coupled plasma optical emission spectrometry (ICP-OES) in equipment of the Agilent brand, model axial 710, in order to quantify the concentration of metals present in the liquors leached from acid digestion with aqua regia $(1 \mathrm{HNO} 3: 3 \mathrm{HCl}$; 24 hours; $25^{\circ} \mathrm{C}$ ). The composition is shown in Table 2 .

\section{Acid leaching in an oxidizing medium}

The non-magnetic fraction of PCBs was leached for $6 \mathrm{~h}$ using $1 \mathrm{M}$ sulfuric acid, 1:10 solid/acid ratio (25g PCBs: $250 \mathrm{~mL}_{2} \mathrm{SO}_{4}$ ) at $75^{\circ} \mathrm{C}$. An oxidizing media was induced by the addition of $10 \mathrm{~mL}$ of $30 \%$ $(\mathrm{v} / \mathrm{v})$ hydrogen peroxide every $30 \mathrm{~min}$ into the system $\left(\mathrm{H}_{2} \mathrm{O}_{2}\right.$ total added $120 \mathrm{~mL}$ ) (Silvas et al., 2015). The liquor from the leaching process was used in solvent extraction tests.

\section{Solvent extraction}

Parameters like the $\mathrm{pH}$ effect, extractant concentration levels the aqueous/organic ratio $(\mathrm{A} / \mathrm{O})$ and extraction isotherms were evaluated. Temperature and time were maintained constant at $25^{\circ} \mathrm{C}$ and 10 min, respectively.

The aqueous phase used in solvent extraction was prepared by diluting copper sulfate pentahydrate $\left(\mathrm{CuSO}_{4} \cdot 5 \mathrm{H}_{2} \mathrm{O}\right)$; nickel sulfate hexahydrate $\left(\mathrm{NiSO}_{4} \cdot 6 \mathrm{H}_{2} \mathrm{O}\right)$; zinc sulfate heptahydrate $\left(\mathrm{ZnSO}_{4} \cdot 7 \mathrm{H}_{2} \mathrm{O}\right)$, ferrous sulfate heptahydrate $\left(\mathrm{FeSO}_{4} \cdot 7 \mathrm{H}_{2} \mathrm{O}\right)$, and aluminum sulfate hydrate $\left(\mathrm{Al}_{2}\left(\mathrm{SO}_{4}\right)_{3} \cdot 18 \mathrm{H}_{2} \mathrm{O}\right)$ in deionized water. All the chemicals used were of analytical grade and purchased from Casa Americana (Brazil).

The extractant used was di-(2-ethylhexyl) phosphoric acid (D2EHPA) from Sigma-Aldrich. The diluent was kerosene of analytical grade from Cromoline Química Fina Ltda (Brazil).

Table 1. Solvent extraction studies for WEEE treatment.

\begin{tabular}{|c|c|c|c|}
\hline Sample & Extractant & Conditions & Reference \\
\hline Sulfuric acid liquor from PCB waste & $\begin{array}{l}1^{\text {st }} \text { step: D2EHPA }(10 \%) \text { diluted in } \\
\text { Kerosene; } 2^{\text {nd }} \text { step: D2EHPA }(20 \%) \\
\text { diluted in Kerosene. }\end{array}$ & $\begin{array}{c}1^{\text {st }} \text { step: } \mathrm{t}=10 \min ; \mathrm{T}=25^{\circ} \mathrm{C} ; \mathrm{pH}= \\
3.5 ; \mathrm{A} / \mathrm{O}=2 / 1 ; 2^{\text {nd }} \text { step: } \mathrm{t}=10 \mathrm{~min} ; \mathrm{T}= \\
25^{\circ} \mathrm{C} ; \mathrm{pH}=3.5 ; \mathrm{A} / \mathrm{O}=1 / 1\end{array}$ & This paper \\
\hline Sulfuric acid from battery waste & $\begin{array}{c}\text { CYANEX } 272(0.72 \mathrm{M}) \text { diluted in } \\
\text { Exxol D-80 }\end{array}$ & $\begin{aligned} \mathrm{t}=20 \min ; \mathrm{T}= & 50^{\circ} \mathrm{C} ; \mathrm{pH}=5.5 ; \mathrm{A} / \mathrm{O} \\
& =1 / 1 .\end{aligned}$ & Dorella and Mansur (2007) \\
\hline Sulfuric acid liquor from battery waste & $\begin{array}{c}\text { CYANEX } 272(0.6 \mathrm{M}) \text { diluted in } \\
\text { Kerosene }\end{array}$ & $\mathrm{t}=20 \min ; \mathrm{pH}=3,6.5$ & Provazi et al. (2011) \\
\hline Sulfuric acid liquor from battery waste & $\begin{array}{l}1^{\text {st }} \text { step: Acorga M5640 }(20 \%) \text { diluted } \\
\text { in Kerosene; } 2^{\text {nd }} \text { step: CYANEX } 272 \\
(0.04 \mathrm{M}) \text { diluted in Kerosene. }\end{array}$ & $\begin{array}{c}1^{\text {st }} \text { step: } \mathrm{t}=5 \mathrm{~min} ; \mathrm{T}=30^{\circ} \mathrm{C} ; \mathrm{O} / \mathrm{A}= \\
1 / 1 ; 2^{\mathrm{n}} \text { step: } \mathrm{pH}=5 ; \mathrm{t}=10 \mathrm{~min} ; \mathrm{T}= \\
25^{\circ} \mathrm{C} ; \mathrm{O} / \mathrm{A}=1 .\end{array}$ & Nayl et a. (2015) \\
\hline Sulfuric acid liquor from PCB waste & $\begin{array}{l}1^{\text {st }} \text { step: TEHA }(70 \%) \text { diluted in } \\
\text { kerosene; } 2^{\text {nd }} \text { step: LIX } 84 \text { IC }(10 \%) \\
\text { diluted in kerosene; } 3^{\text {rd }} \text { step: LIX } 84 \text { IC } \\
(1 \%) \text { diluted in kerosene. }\end{array}$ & $\begin{array}{c}1^{\text {st }} \text { tep: } \mathrm{t}=5 \mathrm{~min} ; \mathrm{T}=30^{\circ} \mathrm{C} \mathrm{O} / \mathrm{A}= \\
2 / 1 ; 2^{\text {nd }} \text { step: } \mathrm{pH}=2.5 ; \mathrm{t}=5 \mathrm{~min} ; \mathrm{O} / \mathrm{A} \\
=1 / 1 ; 3^{\text {rd }} \text { step: } \mathrm{t}=15 \mathrm{~min} ; \mathrm{pH}=4.58 \\
\mathrm{O} / \mathrm{A}=2 / 1\end{array}$ & Kumari et al. (2016) \\
\hline Nitric acid liquor from PCB waste & LIX $984(50 \%)$ & $\mathrm{T}=50^{\circ} \mathrm{C} ; \mathrm{pH}=1.5 ; \mathrm{A} / \mathrm{O}=1 / 1.5$ & Long Le et al. (2011) \\
\hline
\end{tabular}

Table 2. Characterization of PCBs non-magnetic fraction

\begin{tabular}{lllllll}
\hline Metal & $\mathrm{Al}$ & $\mathrm{Cu}$ & $\mathrm{Fe}$ & $\mathrm{Ni}$ & $\mathrm{Zn}$ & Others \\
\hline wt.\% & 2.0 & 33.9 & 0.2 & 0.2 & 3.8 & 7.6 \\
\hline
\end{tabular}




\section{a) Experiments}

The $\mathrm{pH}$ was monitored with a $\mathrm{pH}$ meter and specific glass electrode for solvents. Agitation was maintained constant during all the tests using a mechanical agitator.

Metal extraction $(\% \mathrm{E})$ was calculated from a mass balance (1) of each system studied. Equation 2 was used to calculate the extraction percentage $(\% \mathrm{E})$ for all $\mathrm{A} / \mathrm{O}$ ratio experiments.

$$
\begin{gathered}
\left(C_{i a q}-C_{\text {faq }}\right) V_{a q}=\left(C_{\text {forg }}-C_{\text {iorg }}\right) V_{\text {org }} \\
\text { Extraction percentage }=\frac{C_{\text {forg }}}{C_{\text {forg }}+\frac{V_{a q} C_{i a q}}{V_{\text {org }}}} * 100 \%
\end{gathered}
$$

where $C_{\text {iorg }}$ and $C_{\text {forg }}$ are theinitialandfinalconcentrations of metal in the organic phase, respectively, while the initial and final metal concentrations in the aqueous phase are defined as $C_{i a q}$ and $C_{f a q}$. Furthermore, $V_{a q}$ and $V_{\text {org }}$ are the volumes of the aqueous and organic phases, respectively.

\section{b) Extractant concentration and pH effect}

Initially, the aqueous phase was added to the reactor and mechanical stirring was turned on. The $\mathrm{pH}$ was adjusted to the target value with the addition of $3 \mathrm{M} \mathrm{H}_{2} \mathrm{SO}_{4}$ and $5 \mathrm{M} \mathrm{NaOH}$. Then, the organic phase was mixed with the aqueous phase and the $\mathrm{pH}$ was maintained constant during the experiments.

Mixture separation was achieved in a separation funnel. The aqueous phase was collected and analyzed by the energy dispersive X-ray fluorescence spectrometry (EDX) technique.

In order to evaluate the extractant concentration effect, solvent extraction experiments with 10, 15 and 20\% (v/v) of the extractant diluted with kerosene were performed.

The described procedure was repeated for the $\mathrm{pH}$ values: $1.0 ; 1.5 ; 2.0 ; 2.5 ; 3.0$; and 3.5 .

\section{c) Organic/Aqueous ratio (A/O)}

To evaluate the $\mathrm{A} / \mathrm{O}$ ratio, experiments using $1: 1$ and $2: 1 \mathrm{~A} / \mathrm{O}$ were realized at $25^{\circ} \mathrm{C}$ for $10 \mathrm{~min}$. A $10 \%$ $(\mathrm{v} / \mathrm{v})$ concentration of the extractant D2EHPA was used, diluted in $90 \%(\mathrm{v} / \mathrm{v})$ kerosene, with $\mathrm{pH}$ modified to between 0.5-3.5.

\section{d) Extraction isotherms}

For determining the metal extraction isotherms, the aqueous phase was mixed with the organic phase at different $\mathrm{A} / \mathrm{O}$ ratios. The extraction stage of the individual metal solutions was divided into two parts: i. Initially, zinc and aluminum were separated from the solution with copper and nickel. Tests were conducted at $\mathrm{pH} 3.5$, using $10 \%(\mathrm{v} / \mathrm{v})$ D2EHPA and 90\% (v/v) kerosene. The A/O ratio was modified to between 1:5 and 5:1.

ii. The new aqueous phase (solution with copper and nickel) was stirred with an organic phase comprising 20\% (v/v) D2EHPA and 80\% (v/v) kerosene. The $\mathrm{A} / \mathrm{O}$ ratio varied between $1: 5$ and 5:1 at $\mathrm{pH} 3.5$.

The A/O ratio was varied between 1:5 and 5:1 to determine the number of countercurrent stages, known as McCabe-Thiele Method.

\section{RESULTS AND DISCUSSION}

After hydrometallurgical processing, it was possible to leach zinc, aluminum, copper, nickel and residual iron from video PCBs. Also, with the solvent extraction experiments variables such as the extractant concentration, $\mathrm{pH}$ effect, and $\mathrm{A} / \mathrm{O}$ ratio were evaluated.

\section{Acid leaching in an oxidative medium}

In order to leach copper, other authors (Birloaga et al., 2013; Jha et al., 2011; Yang et al., 2011) also used sulfuric acid and hydrogen peroxide to leach metals from PCBs. The operational conditions used in the present study obtained around 60\% aluminum, 94\% copper, $76 \%$ zinc, $50 \%$ nickel and residual iron from the non-magnetic fraction, while the solution $\mathrm{pH}$ and ORP after the test were 0.5 and $673 \mathrm{mV}$, respectively. Table 3 shows the liquor concentration obtained after the video PCB leaching process.

Table 3. Metal concentration in solution after acid leaching in an oxidizing medium $(\mathrm{pH}=0.5 ; \mathrm{ORP}=673 \mathrm{mV})$.

\begin{tabular}{cc}
\hline Metal & Concentration $(\mathrm{g} / \mathrm{L})$ \\
\hline $\mathrm{Al}$ & 1.20 \\
$\mathrm{Cu}$ & 31.72 \\
$\mathrm{Fe}$ & 0.003 \\
$\mathrm{Ni}$ & 0.11 \\
$\mathrm{Zn}$ & 2.91 \\
\hline
\end{tabular}

After the leaching test, a solid fraction can be used to extract other metals or materials and then it has to be disposed of in landfills. In a study developed by Muniyandi et al. (2013) the non-metallic fraction was used as a filler material in recycled HighDensity Polyethylene (HDPE), recycled high-density polyethylene (rHDPE) and in the production of rHDPE/ PCBs composites. The environmental regulation (balance in strength, stiffness, and toughness) for 
composite materials was attained with the incorporation of a $30 \mathrm{wt} \%$ non-metallic fraction PCBs and $6 \mathrm{phr}$ MAPE (maleic anhydride modified linear low-density polyethylene) compatibilizer (Muniyandi et al., 2013).

\section{Solvent extraction}

Concentration of the synthetic aqueous feed solution is shown in Table 3. The initial $\mathrm{pH}$ of the synthetic solution was adjusted to 0.5 with additions of sulfuric acid.

\section{e) Extractant concentration and the pH effect.}

The extractant concentration effect has been investigated by several authors to analyze metal extraction efficiency from sulfate solutions (Lee et al., 2010; Mohapatra et al., 2007; Vahidi et al., 2009). In this paper, the influence of the D2EHPA concentration was examined in solvent extraction.

As shown in Figure 2, zinc, residual iron, copper and aluminum extractions increased upon increasing the extractant concentration. Also, metal $\mathrm{pH}$ isotherms were displaced to the left with the increase in extractant concentration. As can be seen in Figure 2 (a), the higher metal extractions were achieved when a mixture of $20 \%(\mathrm{v} / \mathrm{v})$ D2EHPA and $80 \%(\mathrm{v} / \mathrm{v})$ kerosene was used. This reflects the fact that the system with $20 \%(\mathrm{v} / \mathrm{v})$ D2EHPA has more extractant molecules than systems with $10 \%(\mathrm{v} / \mathrm{v})$ and $15 \%(\mathrm{v} / \mathrm{v})$ D2EHPA. The metal extraction order found for this system was: $\mathrm{Fe}>\mathrm{Zn}>\mathrm{Al}>\mathrm{Cu}>\mathrm{Ni}$, which is consistent with the results achieved by Sole and Hiskey (1992).

It is known that acid extractants release hydrogen ions during metal extraction and, when metallic cations are extracted, the extractant (D2EHPA) releases hydrogen ions. Metal extraction reactions, equilibrium constants (Keq) and distribution coefficients (D) for divalent and trivalent ions are described in Table 4 (Mansur et al., 2002; Mohapatra et al., 2007).

For divalent and trivalent metals, the distribution coefficient can be calculated by Equation 7. Therefore, considering that the extractant concentration is constant, it follows that:

$$
D=\frac{K_{e q}}{\left[H^{+}\right]^{n}}
$$

Taking the logarithm of Equation 7 and rearranging,

$$
\log D=-n \log \left[H^{+}\right]+\log K_{e q}
$$

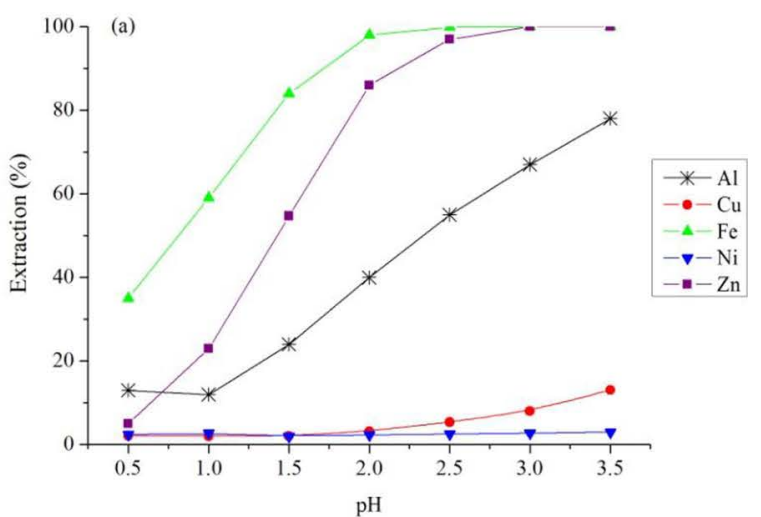

(a)

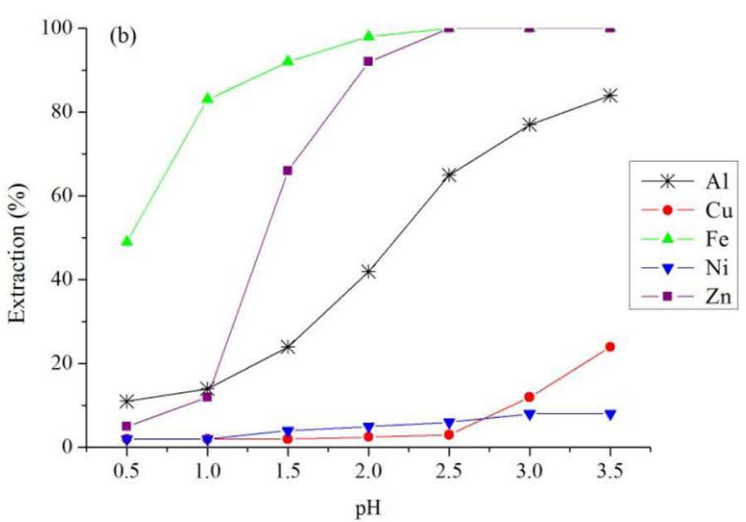

(b)

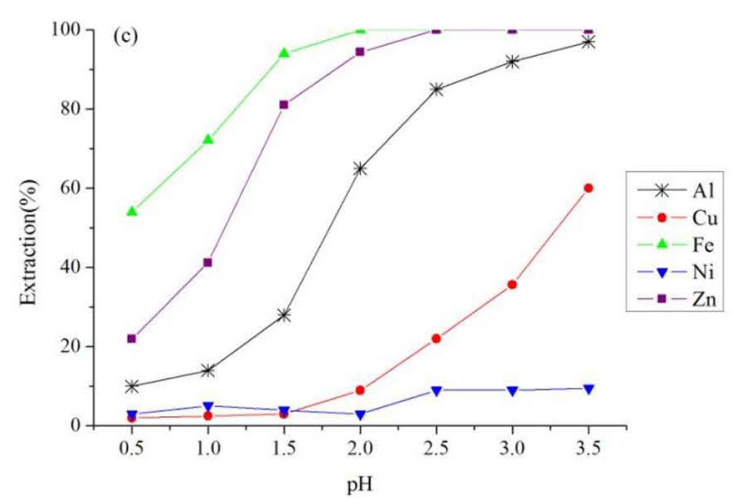

(c)

Figure 2. Effect of extractant concentration in metal extraction: (a) $10 \%(\mathrm{v} / \mathrm{v})$ D2EHPA, (b) $15 \%$ (v/v) D2EHPA and (c) $20 \%(\mathrm{v} / \mathrm{v})$ $\mathrm{D} 2 \mathrm{EHPA}$, diluted with kerosene (contact time $=10 \mathrm{~min}, \mathrm{~A} / \mathrm{O}$ ratio $=1: 1$ and temperature $=25^{\circ} \mathrm{C}$ ).

The values of $\log \mathrm{K}_{\mathrm{eq}}$ and $\mathrm{n}$ are related to the extraction of the metals. Thus, only the metals extracted were considered for the determination of both parameters. Then, the values of $\log \mathrm{K}_{\mathrm{eq}}$ and $\mathrm{n}$ were calculated for aluminum, zinc and iron in the systems that used $10 \% \mathrm{v} / \mathrm{v}$ D2EHPA, 15\% v/v D2EHPA, and $20 \% \mathrm{v} / \mathrm{v}$ D2EHPA (see Table 5). Since copper only 
Table 4. Solvent extraction reactions, equilibrium constants (Keq) and distribution coefficients for divalent and trivalent ions (adapted from Mansur et al., 2002 and Mohapatra et al., 2007).

\begin{tabular}{lcc}
\hline Ion & Extraction Reaction & Equations \\
\hline Divalent metal (Adapted from Mansur et al., 2002) & $M^{+2}+n(R H)_{2} \stackrel{\text { Keq }}{\longrightarrow} M H_{2(n-1)} R_{2 n}+2 H^{+}$ & $K_{e q}=\frac{\left[M H_{2(n-1)} R_{2 n}\right]\left[H^{+}\right]^{2}}{\left[M^{+2}\right]\left[(R H)_{2}\right]^{n}}$ Equation 3 \\
& $D=\frac{\left[M H_{2(n-1)} R_{2 n}\right]}{\left[M^{+2}\right]} \quad$ Equation 4 \\
Trivalent metal (Adapted from Mohapatra et al., 2007) & $M^{+3}+n(R H)_{2} \stackrel{K e q}{\longrightarrow} M H_{2 n-3} R_{2 n}+3 H^{+}$ & $K e q=\frac{\left[M H_{2 n-3} R_{2 n}\right]\left[H^{+}\right]^{3}}{\left[M^{+3}\right]\left[(R H)_{2}\right]^{n}}$ Equation 5 \\
& & $D=\frac{\left[M H_{2 n-3} R_{2 n}\right]}{\left[M^{+3}\right]} \quad$ Equation 6
\end{tabular}

Table 5. Equilibrium value for different organic concentrations (contact time $=10 \mathrm{~min}, \mathrm{~A} / \mathrm{O}$ ratio $=1: 1$ and temperature $=25^{\circ} \mathrm{C}$ )

\begin{tabular}{|c|c|c|c|c|}
\hline Concentration of D2EHPA $(\% \mathrm{v} / \mathrm{v})$ & Metal & $\log$ Keq & $\mathrm{n}$ & $\mathrm{R}$ \\
\hline \multirow{3}{*}{10} & $\mathrm{Al}$ & -1.21 & 0.5 & 0.97 \\
\hline & $\mathrm{Fe}$ & -1.91 & 2.07 & 0.96 \\
\hline & $\mathrm{Zn}$ & -2.82 & 2.09 & 0.94 \\
\hline \multirow{3}{*}{15} & $\mathrm{Al}$ & -1.32 & 0.6 & 0.98 \\
\hline & $\mathrm{Fe}$ & -1.78 & 2.27 & 0.95 \\
\hline & $\mathrm{Zn}$ & -2.91 & 2.35 & 0.93 \\
\hline \multirow{4}{*}{20} & $\mathrm{Al}$ & -1.54 & 0.88 & 0.98 \\
\hline & $\mathrm{Cu}$ & -2.36 & 3.05 & 0.96 \\
\hline & $\mathrm{Fe}$ & -2.71 & 2.66 & 0.92 \\
\hline & $\mathrm{Zn}$ & -2.24 & 0.66 & 0.96 \\
\hline
\end{tabular}

showed increasing extraction with $20 \% \mathrm{v} / \mathrm{v}$ D2EHPA, the equilibrium values were only calculated for this system (Table 5).

The results showed that $\mathrm{pH}$ can directly influence metal extraction capacity. An estimated number of hydrogen ions generated by each metal molecule extracted could be calculated with the experimental data of $\mathrm{D}$ and $\mathrm{pH}$. Equation 4 shows that metal extraction produces hydrogens ions; therefore, the $\mathrm{pH}$ decreases and the metal extraction percentage also decreases.

Figure 3 shows the $\mathrm{pH}$ variation effect in the distribution coefficient of aluminum, copper, iron and zinc.

\section{f) Aqueous/organic ratio (A/O)}

In solvent extraction tests with D2EHPA at an $\mathrm{A} / \mathrm{O}$ ratio of $1: 1$ extractions of zinc, aluminum and copper higher than an A/O ratio of 2:1 (Figure 4) were achieved. However, aluminum and zinc were the metal cations most affected in the solution. For example, at $\mathrm{pH} 3.5$ and an $\mathrm{A} / \mathrm{O}$ ratio of $1: 1$, the extraction percentages for zinc and aluminum were $100 \%$ and $78 \%$, respectively, while at $\mathrm{pH} 3.5$ and an $\mathrm{A} / \mathrm{O}$ ratio of $2: 1$ the $\mathrm{E} \%$ decreased to $84 \%$ and $59 \%$, respectively.

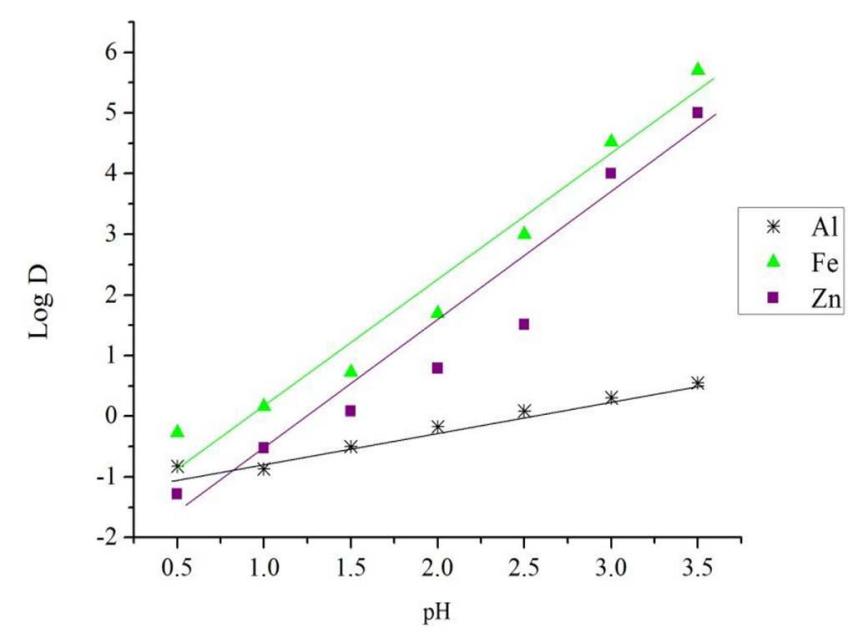

Figure 3. $\mathrm{pH}$ effect on the distribution coefficient of extracted metals: (a) 10\% (v/v) D2EHPA, (b) 15\% (v/v) D2EHPA and (c) $20 \%(\mathrm{v} / \mathrm{v}) \mathrm{D} 2 \mathrm{EHPA}$, diluted with kerosene (contact time $=10 \mathrm{~min}$, $\mathrm{A} / \mathrm{O}$ ratio $=1: 1$ and temperature $=25^{\circ} \mathrm{C}$ ).

The A/O ratio impacts solvent extraction processes. The behavior of the metals during the extraction can change if the $\mathrm{A} / \mathrm{O}$ ratio is modified, even keeping other parameters fixed, such as $\mathrm{pH}$, temperature, and concentration of the extractant. During the solvent extraction process, the fraction of 


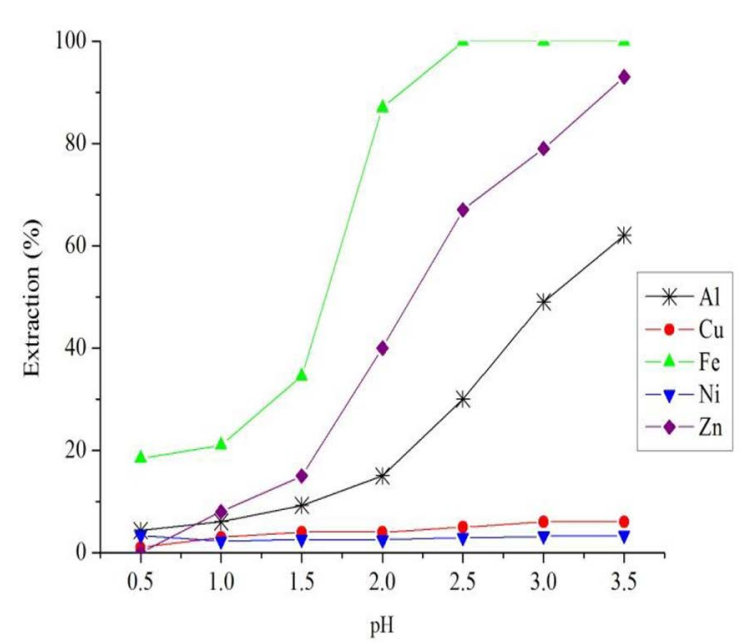

Figure 4. Metal extraction isotherms using an $\mathrm{A} / \mathrm{O}$ ratio of $2: 1$ $($ contact time $=10 \mathrm{~min},[\mathrm{D} 2 \mathrm{EHPA}]=10 \%(\mathrm{v} / \mathrm{v})$, kerosene $=90 \%$ $(\mathrm{v} / \mathrm{v})$ and temperature $\left.=25^{\circ} \mathrm{C}\right)$.

extractant molecules available has to be enough to ensure the extraction of target metal ions (Ritcey and Ashbrook, 1984). When the A/O ratio was changed from $1: 1$ to $2: 1$, the volume of aqueous solution was two times higher, while the extractant capacity was still the same; therefore, the metal extraction was decreased.

\section{Separation parameters}

In solvent extraction, the separation factor is a measure of the selectivity of a solvent for one component over another one. A separation factor higher than one indicates that the separation is favored and can occur.

The separation factors of aluminum, zinc, and residual iron over copper are listed in Table 6. It was found that the selectivity of the solvent for $\mathrm{Al}, \mathrm{Fe}$, and $\mathrm{Zn}$ over copper increased with increasing $\mathrm{pH}$. At the same time, it was observed that the separation factor of $\mathrm{Fe}$ and $\mathrm{Zn}$ increased with increasing extractant concentration as a result of the strongest affinity of D2EHPA for iron and nickel over the other metals in solution.

After evaluation of the separation factors, the variables chosen to carry out the separation of zinc, aluminum and residual iron from the aqueous phase were: $\mathrm{pH}$ of 3.5 , an $\mathrm{A} / \mathrm{O}$ ratio of $2: 1$ and $10 \%(\mathrm{v} / \mathrm{v})$ D2EHPA diluted with kerosene.

The solvent selectivity for copper over nickel is given in Table 7. It was observed that the extraction of copper over nickel was improved with the increase in the $\mathrm{pH}$ and in the D2EHPA concentration. For copper extraction, the parameters adopted were: $\mathrm{pH}$ of 3.5 , A/O ratio of $1: 1$ and $20 \%(\mathrm{v} / \mathrm{v})$ D2EHPA.

Table 6. Separation factors of aluminum, iron, and zinc over copper at different $\mathrm{pH}$ values, $\mathrm{A} / \mathrm{O}$ ratios and at various extractant concentrations.

\begin{tabular}{|c|c|c|c|c|c|c|c|c|c|c|c|c|}
\hline \multirow[b]{3}{*}{$\mathrm{pH}$} & \multicolumn{12}{|c|}{ Separation factor of impurities over copper } \\
\hline & \multicolumn{3}{|c|}{$10 \% \mathrm{v} / \mathrm{v}$ D2EHPA, A/O 1:1 } & \multicolumn{3}{|c|}{ 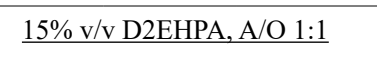 } & \multicolumn{3}{|c|}{$\underline{20 \% \mathrm{v} / \mathrm{v} \text { D2EHPA, A/O 1:1 }}$} & \multicolumn{3}{|c|}{$10 \% \mathrm{v} / \mathrm{v}$ D2EHPA, A/O 2:1 } \\
\hline & $\mathrm{Al}$ & $\mathrm{Fe}$ & $\mathrm{Zn}$ & $\mathrm{Al}$ & $\mathrm{Fe}$ & $\mathrm{Zn}$ & $\mathrm{Al}$ & $\mathrm{Fe}$ & $\mathrm{Zn}$ & $\mathrm{Al}$ & $\mathrm{Fe}$ & $\mathrm{Zn}$ \\
\hline 0.5 & 6.6 & 23.8 & 2.3 & 6.3 & 46.5 & 4.3 & 5.4 & 57.5 & 14.1 & 4.5 & 46.3 & 0.0 \\
\hline 1.0 & 6.7 & 70.5 & 14.6 & 6.4 & 239.2 & 17.2 & 6.3 & 104.5 & 28.4 & 2.1 & 15.6 & 2.8 \\
\hline 1.5 & 15.1 & 250.8 & 57.7 & 9.1 & 281.9 & 48.4 & 12.6 & 525.3 & 142.9 & 2.4 & 23.0 & 4.2 \\
\hline 2.0 & 20.2 & 1482.3 & 185.8 & 19.1 & 1922.1 & 291.1 & 18.8 & $1.1 \mathrm{E}+05$ & 174.9 & 4.2 & 281.3 & 16.0 \\
\hline 2.5 & 21.4 & 17501.0 & 566.4 & 20.1 & $1.5 \mathrm{E}+05$ & 1221.0 & 20.1 & $5.4 \mathrm{E}+05$ & $3.6 \mathrm{E}+05$ & 8.1 & $2.2 \mathrm{E}+05$ & 38.6 \\
\hline 3.0 & 23.3 & $3.8 \mathrm{E}+05$ & $1.1 \mathrm{E}+05$ & 20.9 & $1.8 \mathrm{E}+06$ & $7.33 \mathrm{E}+05$ & 20.8 & $2.9 \mathrm{E}+05$ & $1.9 \mathrm{E}+06$ & 15.1 & $4.1 \mathrm{E}+05$ & 58.9 \\
\hline 3.5 & 23.5 & $3.3 \mathrm{E}+06$ & $6.6 \mathrm{E}+05$ & 21.8 & $1.8 \mathrm{E}+07$ & $1.77 \mathrm{E}+06$ & 21.6 & $8.3 \mathrm{E}+08$ & $3.6 \mathrm{E}+06$ & 25.6 & $9.5 \mathrm{E}+06$ & 208.1 \\
\hline
\end{tabular}

Table 7. Separation factors of copper over nickel at different $\mathrm{pH}$ values, $\mathrm{A} / \mathrm{O}$ ratios and at various extractant concentrations.

\begin{tabular}{lcccc}
\hline \multicolumn{5}{c}{ Separation factor of copper over nickel } \\
\hline $\mathrm{pH}$ & $10 \% \mathrm{v} / \mathrm{v}$ D2EHPA, A/O 1:1 & $15 \%$ v/v D2EHPA, A/O 1:1 & $20 \%$ v/v D2EHPA, A/O 1:1 & $10 \%$ v/v D2EHPA, A/O 2:1 \\
\hline 0.5 & 1.0 & 1.0 & 0.7 & 0.29 \\
1.0 & 1.0 & 1.3 & 0.5 & 1.37 \\
1.5 & 1.0 & 1.3 & 0.7 & 1.56 \\
2.0 & 1.6 & 1.4 & 2.9 & 1.63 \\
2.5 & 2.4 & 1.4 & 5.6 & 1.76 \\
3.0 & 3.1 & 1.8 & 14.3 & 1.93 \\
3.5 & 4.9 & 3.7 & & 1.81 \\
\hline
\end{tabular}




\section{McCabe-Thiele isotherms}

To plot the extraction isotherms of metals, experiments were performed in two steps: i) the extraction of zinc, residual iron and aluminum, and ii) solvent extraction trials to separate copper from nickel.

\section{g) Zinc, residual iron and aluminum extraction}

The synthetic solution simulating the oxidant acid liquor (Table 2) was put in contact with a solution of $10 \%(\mathrm{v} / \mathrm{v})$ D2EHPA diluted with kerosene and using $\mathrm{A} / \mathrm{O}$ ratios between $1: 5$ and 5:1. To construct McCabe-Thiele diagrams for aluminum and zinc extraction (see Figure 5), the $\mathrm{pH}$ was maintained

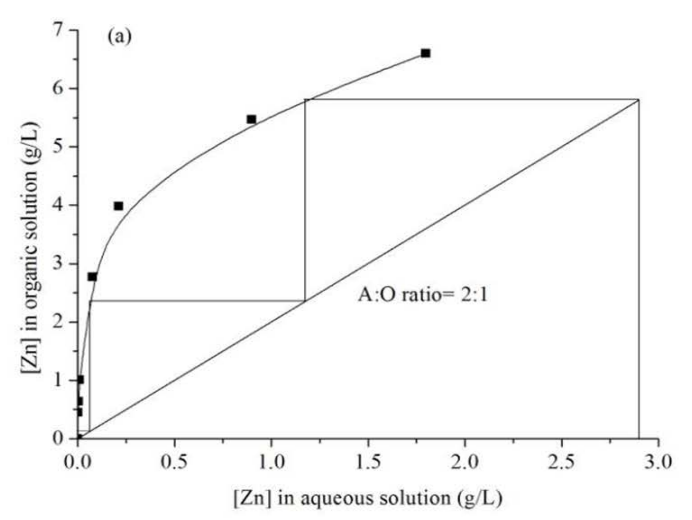

(a)

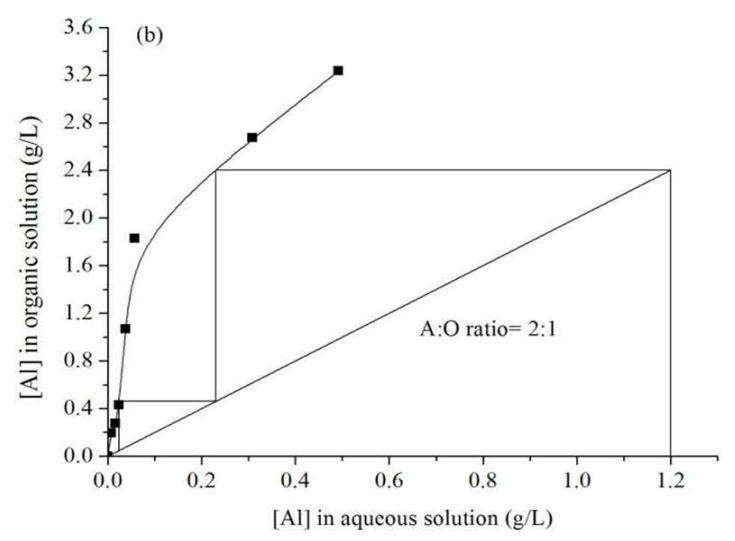

(b)

Figure 5. McCabe-Thiele diagram to extract (a) zinc and (b) aluminum using $10 \%(\mathrm{v} / \mathrm{v})$ D2EHPA diluted with kerosene, at $25^{\circ} \mathrm{C}, \mathrm{pH} 3.5$. constant at 3.5. It was possible to verify that both zinc and aluminum can be extracted with two theoretical stages, although zinc, residual iron and aluminum cannot be separated from each other, as shown in Figure 2(a). Extraction of residual iron was achieved with one countercurrent stage. Therefore, in this case, a McCabe-Thiele diagram is not necessary.

Figure 5 (a) shows that two theoretical stages were needed to separate zinc from a synthetic solution using a 2:1 A/O ratio, and Figure 5 (b) shows that two theoretical stages were needed to extract aluminum from the aqueous phase using $2: 1 \mathrm{~A} / \mathrm{O}$.

D2EHPA is commonly used to separate zinc from solutions that contain metals. Pereira et al., 2007) investigated the extraction of $11.9 \mathrm{~g} / \mathrm{L}$ of zinc from a solution with other metals like iron, magnesium, manganese and calcium. The work reported that zinc extraction using 20\% (v/v) D2EHPA and an A/O ratio was possible with two theoretical stages.

Furthermore, D2EHPA can separate aluminum from solutions with other metals. Mohapatra et al. (2007) studied aluminum extraction from a solution by 0.3M D2EHPA. The investigation found that two theoretical stages were required to extract aluminum from the aqueous phase.

\section{h) Copper extraction}

To determine the number of theoretical stages to separate copper from a solution with nickel, 20\% (v/v) D2EHPA diluted with $80 \%$ (v/v) kerosene was mixed with the aqueous phase at $\mathrm{pH} 3.5$. As shown in Figure 6 , at an $\mathrm{A} / \mathrm{O}$ ratio of $1: 1$, with two theoretical stages, copper was completely separated from nickel.

Similar to a study developed by Pranolo et al., 2010), in this study, it was observed that, in the organic phase, the copper concentration increased with the increase in the $\mathrm{A} / \mathrm{O}$ ratio.

While copper is extracted by the organic phase (20\% (v/v) D2EHPA diluted with kerosene), nickel remained in the aqueous phase and can be recovered by an electrolysis process. The organic solution with copper must be forwarded to the stripping stage before copper recovery by the electrowinning technique. Total copper extraction from a liquor produced in the leaching process of the non-magnetic fraction of PCBs was carried out using the present process. 


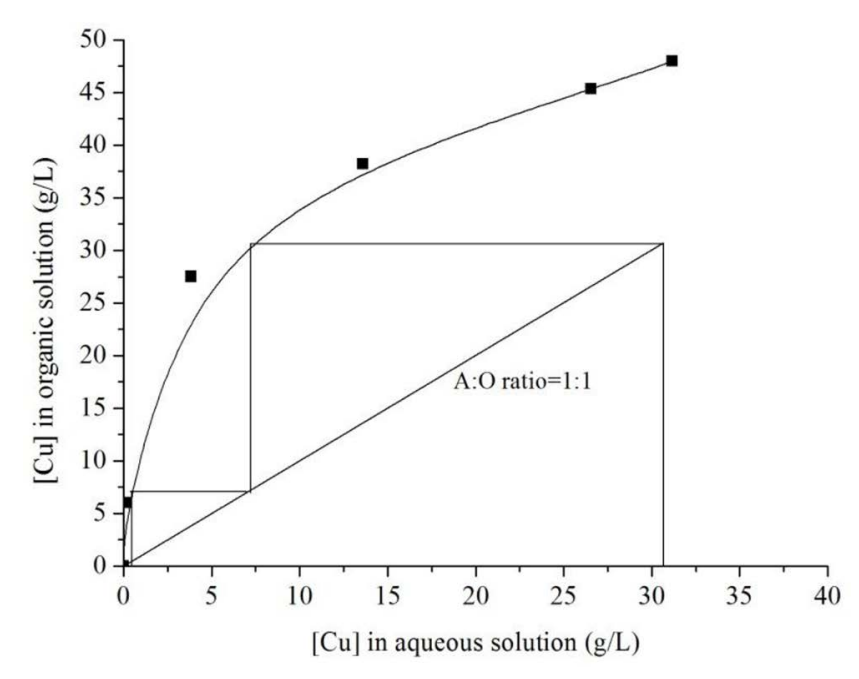

Figure 6. McCabe-Thiele plot for copper extraction. Organic phase $=20 \%(\mathrm{v} / \mathrm{v})$ D2EHPA and $80 \%(\mathrm{v} / \mathrm{v})$ kerosene, contact time $=10 \mathrm{~min}$, temperature $=25^{\circ} \mathrm{C}$ and $\mathrm{pH}=3.5$

\section{CONCLUSIONS}

PCBs from discarded computers of metals such as copper, nickel, zinc and aluminum can be used as raw materials. At the end of the present study three-metal solutions were obtained: (a) a solution comprising residual iron, aluminum, and zinc, (b) a solution comprising copper and (c) a solution of nickel. In addition, it was found that:

- In the leaching step using $1 \mathrm{M} \mathrm{H}_{2} \mathrm{SO}_{4}$ and an oxidant medium, at $75^{\circ} \mathrm{C}, 60 \%$ aluminum, and $76 \%$ zinc, $94 \%$ copper, and $50 \%$ nickel were leached from the non-magnetic fraction of video $\mathrm{PCBs}$ after $6 \mathrm{~h}$ of reaction.

- It is possible to extract $100 \%$ of the zinc and aluminum present in the leaching liquor from the non-magnetic fraction of PCBs using $10 \%(\mathrm{v} / \mathrm{v})$ D2EHPA diluted with $90 \%$ (v/v) kerosene, $\mathrm{pH} 3.5$, $25^{\circ} \mathrm{C}, 10 \mathrm{~min}$ of reaction time and an $\mathrm{A} / \mathrm{O}$ ratio of $2: 1$. The number of theoretical extraction contacts for the countercurrent separation system is two.

- Total copper extraction from a liquor produced in the leaching process of the non-magnetic fraction of PCBs can be carried out in two theoretical contacts at an $\mathrm{A} / \mathrm{O}$ ratio of $1: 1,25^{\circ} \mathrm{C}, 10 \mathrm{~min}$ of reaction, $\mathrm{pH} 3.5$ and using $20 \%(\mathrm{v} / \mathrm{v})$ D2EHPA diluted with $80 \%(\mathrm{v} / \mathrm{v})$ kerosene, provided that aluminum and zinc are previously extracted.

\section{ACKNOWLEDGMENTS}

This work was carried out with financial support from FAPESP (Grants No 2012/20350-3, No 2013/22614-0 and research project 2012/51871-9), CNPq (Research fellowship No 500869/2014-6) and CAPES (PNPD-2010 Program).

\section{NOMENCLATURE}

$\%$ E - Extraction percent

$\mathrm{A} / \mathrm{O}$ - Aqueous/Organic

$\mathrm{C}_{\text {faq }}$ - Final concentration of metal in the aqueous phase

$\mathrm{C}_{\text {forg }}$ - Final concentration of metal in the organic phase

$\mathrm{C}_{\mathrm{iaq}}$ - Initial concentration of metal in the aqueous phase

$\mathrm{C}_{\text {iorg }}$ - Initial concentration of metal in the organic phase

D - Distribution coefficient

D2EHPA - Di-2-ethylhexyl phosphoric acid

EDX - Energy dispersive X-ray Fluorescence Spectrometry

EEE - Electrical and Electronic Equipment

Keq - Equilibrium constant

LIX 26 - Alkylated 8-hydroxyquinoline

$\mathrm{M}^{+2}$ - Divalent metal

$\mathrm{M}^{+3}$ - Trivalent metal

$\mathrm{MH}_{2(\mathrm{n} 1)} \mathrm{R}_{2 \mathrm{n}}$ - Organic complex formed between the extractant and divalent metal

$\mathrm{MH}_{2 \mathrm{n} 3} \mathrm{R}_{2 \mathrm{n}}$ - Organic complex formed between the extractant and trivalent metal

$\mathrm{n}$ - Stoichiometric constant

PCBs - Printed Circuit Boards

$(\mathrm{RH})_{2}$ - Dimeric form of extractantr

HDPE - Recycled high density polyethylene

(HDPE) - High-Density Polyethylene

$\mathrm{V}_{\mathrm{aq}}$ - Volume of the aqueous phase

$\mathrm{V}_{\mathrm{org}}$ - Volume of the organic phase

WEEE - Waste electrical and electronic equipment

\section{REFERENCES}

Baldé, C., Wang, F., Kuehr, R., and Huisman, J. (2015). The global e-waste monitor 2014. United Nations University, IAS-SCYCLE, Bonn, Germany.

Birloaga, I., De Michelis, I., Ferella, F., Buzatu, M., and Vegliò, F., Study on the influence of various factors in the hydrometallurgical processing of waste printed circuit boards for copper and gold recovery. Waste Management, 33(4), 935941 (2013). doi: http://dx.doi.org/10.1016/j. wasman.2013.01.003

Chen, M., Zhang, S., Huang, J., and Chen, H., Lead during the leaching process of copper from waste printed circuit boards by five typical ionic liquid acids. Journal of Cleaner Production, 95, 142147 (2015). doi: http://dx.doi.org/10.1016/j. jclepro.2015.02.045

Clyde F. Coombs, Jr. (2008). Printed Circuits Handbook, SixthEdition Printed Circuits Handbook, Sixth Edition: McGraw Hill Professional, Access Engineering. 
Cui, J. and Zhang, L., Metallurgical recovery of metals from electronic waste: A review. Journal of Hazardous Materials, 158(2-3), 228-256(2008). doi: http://dx.doi.org/10.1016/j.jhazmat.2008.02.001

Dalrymple, I., Wright, N., Kellner, R., Bains, N., Geraghty, K., Goosey, M., and Lightfoot, L., An integrated approach to electronic waste (WEEE) recycling. Circuit World, 33(2), 52-58 (2007). doi: 10.1108/03056120710750256

Dorella, G., and Mansur, M. B., A study of the separation of cobalt from spent Li-ion battery residues. Journal of Power Sources, 170(1), 210-215 (2007). doi: http:// dx.doi.org/10.1016/j.jpowsour.2007.04.025

European Parliament. (2003a). Directive 2002/96/EC of the European Parliament and of the Council on waste electrical and electronic equipment (WEEE). Official Journal of the European Union, (13).

European Parliament. (2003a). Directive 2002/95/EC of the European Parliament and of the Council on the Restriction of the Use of Certain Hazardous Substances in Electrical and Electronic Equipment (RoHS). Official Journal of the European Union.

Flandinet, L., Tedjar, F., Ghetta, V., and Fouletier, J., Metals recovering from waste printed circuit boards (WPCBs) using molten salts. Journal of Hazardous Materials, 213-214, 485-490 (2012). doi: http:// dx.doi.org/10.1016/j.jhazmat.2012.02.037

Fogarasi, S., Imre-Lucaci, F., Ilea, P., and Imre-Lucaci, Á., The environmental assessment of two new copper recovery processes from Waste Printed Circuit Boards. Journal of Cleaner Production, 54, 264-269 (2013). doi: http://dx.doi.org/10.1016/j.jclepro.2013.04.044

Ghosh, B., Ghosh, M. K., Parhi, P., Mukherjee, P. S., and Mishra, B. K., Waste Printed Circuit Boards recycling: an extensive assessment of current status. Journal of Cleaner Production, 94, 5-19 (2015). doi: http://dx.doi.org/10.1016/j.jclepro.2015.02.024

Hagelüken, C., Recycling of electronic scrap at Umicore's integrated metals smelter and refinery. Ezmerall, 59, 152-161(2006).

Hall, W. J., and Williams, P. T., Separation and recovery of materials from scrap printed circuit boards. Resources, Conservation and Recycling, 51(3), 691-709 (2007). doi: http://dx.doi.org/10.1016/j. resconrec.2006.11.010

Hanafi, J., Jobiliong, E., Christiani, A., Soenarta, D. C., Kurniawan, J., and Irawan, J., Material Recovery and Characterization of PCB from Electronic Waste. Procedia - Social and Behavioral Sciences, 57(0), 331-338 (2012). doi: http://dx.doi. org/10.1016/j.sbspro.2012.09.1194
Jha, M., Lee, J.-c., Kumari, A., Choubey, P., Kumar, V., and Jeong, J., Pressure leaching of metals from waste printed circuit boards using sulfuric acid. The Journal of The Minerals, Metals \& Materials Society (JOM), 63(8), 29-32 (2011). doi: 10.1007/s11837-011-0133-z

Jiménez Correa, M. M., Arold L, Moraes V.T, Tenório J.A.S, and Espinosa D C R. (2014). Characterization of video printed circuit boards from computers. Paper presented at the 4th International Conference on Industrial and Hazardous Waste Management, Crete.

Kane, A. (2015). UK IS 'THE WORLD'S FIFTH LARGEST PRODUCER OF WEEE'. Retrieved 22/09/2015, 2015, from http://resource.co/article/ uk-worlds-fifth-largest-producer-weee-10044

Kumari, A., Jha, M. K., Lee, J.-C., and Singh, R. P., Clean process for recovery of metals and recycling of acid from the leach liquor of PCBs. Journal of Cleaner Production, 112(5), 4826-4834 (2016). doi: http://dx.doi.org/10.1016/j.jclepro.2015.08.018

LaDou, J., Printed circuit board industry. International Journal of Hygiene and Environmental Health, 209(3), 211-219 (2006). doi: http://dx.doi. org/10.1016/j.ijheh.2006.02.001

Lee, J. Y., Pranolo, Y., Zhang, W., and Cheng, C. Y., The Recovery of Zinc and Manganese from Synthetic Spent Battery Leach Solutions by Solvent Extraction. Solvent Extraction and Ion Exchange, 28(1), 73-84 (2010). doi: 10.1080/07366290903409043

Long Le, H., Jeong, J., Lee, J.-C., Pandey, B. D., Yoo, J.-M., and Huyunh, T. H., Hydrometallurgical Process for Copper Recovery from Waste Printed Circuit Boards (PCBs). Mineral Processing and Extractive Metallurgy Review, 32(2), 90-104 (2011). doi: 10.1080/08827508.2010.530720

Mansur, M. B., Slater, M. J., and Biscaia Jr, E. C., Equilibrium analysis of the reactive liquidliquid test system $\mathrm{ZnSO} / \mathrm{D} 2 \mathrm{EHPA} / \mathrm{n}$-heptane. Hydrometallurgy, 63(2), 117-126 (2002). doi: http://dx.doi.org/10.1016/S0304-386X(01)00211-0

Mecucci, A., and Scott, K., Leaching and electrochemical recovery of copper, lead and tin from scrap printed circuit boards. Journal of Chemical Technology \& Biotechnology, 77(4), 449-457 (2002). doi: 10.1002/jctb.575

Mohapatra, D., Hong-In K., Nam C W., and Park K H., Liquid-liquid extraction of aluminium(III) from mixed sulphate solutions using sodium salts of Cyanex 272 and D2EHPA. Separation and Purification Technology, 56(3), 311-318 (2007). doi: http://dx.doi.org/10.1016/j.seppur.2007.02.017 
Muniyandi, S. K., Sohaili, J., and Hassan, A., Mechanical, thermal, morphological and leaching properties of nonmetallic printed circuit board waste in recycled HDPE composites. Journal of Cleaner Production, 57, 327-334 (2013). doi: http:// dx.doi.org/10.1016/j.jclepro.2013.05.033

Nayl, A. A., Hamed, M. M., and Rizk, S. E., Selective extraction and separation of metal values from leach liquor of mixed spent Li-ion batteries. Journal of the Taiwan Institute of Chemical Engineers, 55, 119-125 (2015). doi: http://dx.doi.org/10.1016/j. jtice.2015.04.006

Oh, C. J., Lee, S. O., Yang, H. S., Ha, T. J., and Kim, M. J., Selective Leaching of Valuable Metals from Waste Printed Circuit Boards. Journal of the Air \& Waste Management Association, 53(7), 897-902 (2003). doi: 10.1080/10473289.2003.10466230

Oishi, T., Koyama, K., Alam, S., Tanaka, M., and Lee, J. C., Recovery of high purity copper cathode from printed circuit boards using ammoniacal sulfate or chloride solutions. Hydrometallurgy, 89(12), 82-88(2007). doi: http://dx.doi.org/10.1016/j. hydromet.2007.05.010

Park, Y. J., and Fray, D. J., Recovery of high purity precious metals from printed circuit boards. Journal of Hazardous Materials, 164(2-3), 11521158(2009). doi: http://dx.doi.org/10.1016/j. jhazmat.2008.09.043

Pereira, D. D. (2006). Recuperação de zinco presente em efluentes industriais produzidos pela votorantim metais unidade três marias utilizando-se a técnica de extração líquido-líquido. (Mestre), Universidade Federal de Minas Gerais (UFMG), Belo Horizonte.

Pereira, D. D., Rocha S. D. F., and Mansur M. B., Recovery of zinc sulphate from industrial effluents by liquid-liquid extraction using D2EHPA (di2-ethylhexyl phosphoric acid). Separation and Purification Technology, 53(1), 89-96 (2007). doi: http://dx.doi.org/10.1016/j.seppur.2006.06.013

Pranolo, Y., Zhang, W., and Cheng, C. Y., Recovery of metals from spent lithium-ion battery leach solutions with a mixed solvent extractant system. Hydrometallurgy, 102(1-4), 37-42(2010). doi: http://dx.doi.org/10.1016/j.hydromet.2010.01.007

Provazi, K., Campos, B. A., Espinosa, D. C. R., and Tenório, J. A. S., Metal separation from mixed types of batteries using selective precipitation and liquid-liquid extraction techniques. Waste Management, 31(1), 59-64 (2011). doi: http:// dx.doi.org/10.1016/j.wasman.2010.08.021
Ritcey, G. M., and Ashbrook, A. W. (1984). Solvent extraction principles and applications to process metallurgy. Part I (Vol. I). Amsterdam: Elsevier.

Rocchetti, L., Vegliò, F., Kopacek, B., and Beolchini, F., Environmental Impact Assessment of Hydrometallurgical Processes for Metal Recovery from WEEE Residues Using a Portable Prototype Plant. Environmental Science \& Technology, 47(3), 1581-1588 (2013). doi: $10.1021 / \mathrm{es} 302192 \mathrm{t}$

Silvas F. P. C., Jiménez Correa M. M., Caldas M. P. K., de Moraes V.T., Espinosa D. C. R., and Tenório J. A. S., Printed circuit board recycling: Physical processing and copper extraction by selective leaching. Waste Management, 46, 503510 (2015). doi: http://dx.doi.org/10.1016/j. wasman.2015.08.030

Sole, K. C., and Hiskey, J. B., Solvent extraction characteristics of thiosubstituted organophosphinic acid extractants. Hydrometallurgy, 30(1-3), 345365(1992). doi: http://dx.doi.org/10.1016/0304386X(92)90093-F

Streicher-Porte, M., Widmer, R., Jain, A., Bader, H.-P., Scheidegger, R., and Kytzia, S., Key drivers of the e-waste recycling system: Assessing and modelling e-waste processing in the informal sector in Delhi. Environmental Impact Assessment Review, 25(5), 472-491 (2005). doi: http://dx.doi.org/10.1016/j. eiar.2005.04.004

Tuncuk, A., Stazi, V., Akcil, A., Yazici, E. Y., and Deveci, H., Aqueous metal recovery techniques from e-scrap: Hydrometallurgy in recycling. Minerals Engineering, 25(1), 28-37 (2012). doi: http://dx.doi.org/10.1016/j.mineng.2011.09.019

Vahidi, E., Rashchi, F., and Moradkhani, D., Recovery of zinc from an industrial zinc leach residue by solvent extraction using D2EHPA. Minerals Engineering, 22(2), 204-206 (2009). doi: http:// dx.doi.org/10.1016/j.mineng.2008.05.002

Yamane Luciana Harue, Moraes V. T. de, Espinosa D. C. R., and Tenório J.A. S., Recycling of WEEE: Characterization of spent printed circuit boards from mobile phones and computers. Waste Management, 31(12), 2553-2558 (2011). doi: http://dx.doi.org/10.1016/j.wasman.2011.07.006

Yang, H., Liu, J., and Yang, J., Leaching copper from shredded particles of waste printed circuit boards. Journal of Hazardous Materials, 187(1-3), 393-400(2011). doi: http://dx.doi.org/10.1016/j. jhazmat.2011.01.051 
